\title{
Nutrient Requirements in Preterm Infants
}

\author{
A review of: Klein CJ 2002 Nutrient Requirements for Preterm Infant Formulas. J Nutr 132:1395S-1577S
}

$T^{\prime}$ HE FUNDAMENTAL PRINCIPLE underlying nutritional care is that intake meets requirements thereby ensuring that poor nutrition is not rate limiting on clinical outcome. This raises particular difficulties in the pre-term infant. It takes time to establish an adequate intake in the sick unstable infant $(1,2)$. At the same time, nutritional requirements and measures of outcome are not fully defined for these high-risk infants.

Recognizing these difficulties, recommendations on nutrient requirements in pre-term infants have been drawn up by the European Society of Paediatric Gastroenterology and Nutrition $(3,4)$, American Academy of Pediatrics $(5,6)$ and the Canadian Pediatric Society (7). More recently, under a remit from the Food and Drug Administration, an ad-hoc expert panel was convened by the Life Sciences Research Office of the American Society for Nutritional Sciences to review this issue (8).

The scope of this review was enormous but the fundamental question addressed was whether scientific evidence existed to indicate that nutrient requirements for preterm infant formulas differed from those for term infant formulas.

Recommendations were, therefore, developed for infants a) born $<36$ weeks gestation and/or weighing 750-2500 $\mathrm{g}$ at birth, b) in whom formula was the sole source of nutrition, c) between 10 days and 1 year of age. Because of lack of data, it was decided that needs for infants weighing $<750 \mathrm{~g}$ at birth were unknown.

Because outcomes were better in preterm infants fed a preterm compared to a term infant formula $(9,10)$ and in infants fed fortified human milk compared to unfortified human milk (11-13) the panel also decided neither term infant formula nor unfortified human milk were appropriate reference standards for the calculation of nutrient needs in these infants.

In the absence of suitable alternatives but keenly aware of the inherent problems associated with the growth charts and nutrient balance studies, the panel determined

\section{Richard J. CoOKe}

that intra-uterine growth and fetal nutrient accretion rates were key outcome variables when assessing adequacy of intake.

Establishing minimum and maximum nutrient levels for preterm infant formulas were the prime remit for the panel. Minimum levels were based on nutrient level in term formulas, intra-uterine accretion and scientific evidence to support adequacy. Maximum levels were based on evidence or lack of evidence of toxicity from feeding studies, clinical experience and history of use.

The panel must be congratulated on the quality of their work in such a complex subject. This publication is an important reference point for the ongoing formulation of the nutrient content of preterm formulas and for those with a keen interest in nutritional support of the preterm infant. However, a nagging question remains.

The panel determined that adequacy of intake be related to a rate of weight gain which paralleled that in-utero. In effect, a 26 week gestation infant who regains body weight by the end of the second to fourth week of life, then gains weight at the in-utero rate $(\sim 30 \mathrm{~g} / \mathrm{d})$ will be $420-840 \mathrm{~g}$ lighter than the intra-uterine fetus at 36 weeks gestation.

Is this acceptable or should the target weight gain also aim for catch-up growth? The panel determined that recommended range of intake of a specific nutrient also be intended for catch-up growth. Yet, this issue is not directly addressed and is critical, particularly in the smaller more immature infant who has had a complicated neonatal course.

Such, perhaps, is the current state of the art. Future research must determine whether such weight differences are functionally relevant and whether intervention by also aiming for catch-up will improve outcome. Given the wide variability in nutritional status between preterm infants and the need to fine-tune intake accordingly, weight gain reference standards must be more precisely defined in this nutritionally vulnerable population.
1. Carlson SJ, Ziegler EE 1998 Nutrient intakes and growth of very low birth weight infants. J Perinatol 18:252-258

2. Embleton NE, Pang N, Cooke RJ 2001 Postnatal malnutrition and growth retardation: an inevitable consequence of current recommendations in preterm infants? Pediatrics 107:270-273

3. ESPGAN 1987 Nutrition and feeding of preterm infants. Blackwell Scientific Publications, Oxford

4. ESPGAN-CON 1993 Comparison of enteral intake recommendations. In: Tsang R, Lucas A, Uauy R, Zlotkin S (eds) Nutritional needs of the preterm infant. Williams \& Wilkins, Baltimore, p 296

5. AAPCON 1993 Nutritional needs of preterm infants. In: Barness L (ed) Pediatric Nutrition Handbook. American Academy of Pediatrics, Elk Groove Village, pp 64-89

6. AAPCON 1998 Nutritional needs of preterm infants. In: Kleinman RE (ed) Pediatric Nutrition Handbook. American Academy of Pediatrics, Elk Groove Village, pp 55-88

7. Nutrition Committee, Canadian Paediatric Society 1995 Nutrient needs and feeding of premature infants. CMAJ 152:1765-1785

8. Klein CJ 2002 Nutrient requirements for preterm infant formulas. J Nutr 132:1395S-1577S

9. Lucas A, Morley R, Cole TJ 1998 Randomised trial of early diet in preterm babies and later intelligence quotient. BMJ 317:1481-1487

10. Cooke RJ, Nichoalds G 1986 Nutrient retention in preterm infants fed standard infant formulas. J Pediatr 108:448-451

11. Anderson GH, Atkinson SA, Bryan MH 1981 Energy and macronutrient content of human milk during early lactation from mothers giving birth prematurely and at term. Am J Clin Nutr 34:258 265

12. Lucas A, Hudson GJ 1984 Preterm milk as a source of protein for low birth weight infants. Arch Dis Child 59:831-836

13. Atkinson SA, Radde IC, Anderson GH 1983 Macromineral balances in premature infants fed their own mothers' milk or formula. J Pediatr 102:99106

Department of Pediatrics

University of Tennessee Center for Health Sciences

853 Jefferson Ave.

Memphis, TN 38163

U.S.A.

rcooke@utmem.edu

DOI: 10.1203/01.PDR.0000048665.88001.0A 